\title{
LIQUID-PHASE POLYMER-BASED RETENTION TO REMOVE ARSENIC FROM WATER
}

\author{
JULIO SÁNCHEZ ${ }^{1}$, BERNABÉ L. RIVAS ${ }^{2, *}$ \\ ${ }^{1}$ Departamento de Ciencias del Ambiente, Facultad de Química y Biología, Universidad de Santiago de Chile, USACH, Casilla 40, \\ Correo 33, Santiago, Chile. \\ ${ }^{2}$ Polymer Department, Faculty of Chemistry, University of Concepción, Casilla 160-C, Concepción, Chile.
}

\begin{abstract}
The functional polymer materials have presented a great development in adsorption processes for the treatment of polluted waters. The aim of the current review is to present the developments during the few last years in this field of study by examining research of systems like water-functional soluble polymers and electro-oxidation process coupled to ultrafiltration membranes for decontamination processes in liquid-liquid phase. The study is addressed to arsenic which is considered one of the most hazardous contaminants.
\end{abstract}

Keywords: Water-soluble polymers, Membranes, Arsenic, Removal.

\section{INTRODUCTION}

Water pollution is a major global problem that requires ongoing evaluation and revision of water resource policies at all levels, from the international level down to the level of individual aquifers and wells. It has been suggested that water pollution is the leading cause of death and diseases worldwide. Water pollution accounted for the deaths of 1.8 million people in 2015 .

Pure water is increasingly becoming a rare resource on Earth because human activities release increasing amounts of soluble chemical species that are not appropriately removed before returning the water to the environment. Among these polluting species, metal ions, oxyanions, emerging antibiotics, dyes, etc., are of concern because of their high toxicity. Streams of process wastes from mining operations, metal-plating facilities, power generation facilities, electronic device manufacturing units, tanneries, battery manufacturing, and paper industries contain one or more toxic metal ions, and tanneries often contain metal ions at concentrations above the local discharge limits. Unlike organic contaminants, metals and semimetals are not biodegradable and tend to accumulate in living organisms, and many heavy metal ions are known to be toxic or carcinogenic and not biodegradable.

Metal ions and oxyanions are priority pollutants due to their mobility in natural water ecosystems and their toxicity [1,2]. These ions are stable and persistent environmental contaminants, since they cannot be degraded and destroyed and are thus considered bioaccumulable substances that can be harmful to aquatic life. Water contaminated by toxic metal ions remains a serious public health problem, and exposure to a trace amount of these pollutants is considered a risk for human beings. Therefore, all over the world, industry has been forced to reduce the contents of metals and oxyanions in water and industrial wastewaters to acceptable levels. The current environmental regulations of these pollutants are increasingly stringent, whereas the global need for most of these pollutants continues to increase as a result of the rapid development of modern industries. Thus, there is an urgent need to develop efficient and effective techniques for processing wastewater containing soluble metal ion pollutants. The efficient removal of metal ions from water systems is an important and interesting task for environmental engineers.

Many technologies, such as chemical precipitation, ion exchange, adsorption, coagulation, chemical precipitation, and membrane filtration, have been adopted to remove poisonous metal ions from water [3-13]. Recently, numerous approaches have been proposed for the development of low-cost and more effective technologies for water purification. Adsorption has proven to be cost effective and successful for removing heavy metals, organic pollutants, and dyes from water systems. Adsorbents have attracted substantial attention due to the accessibility of various adsorbent types, their environmentally friendly characteristics, their cost viability, and their high effectiveness in the removal of organic and inorganic pollutants. There are several important standards, such as fast removal, ion selectivity, and reusability, that govern the selection and design of adsorbents [14,15]. Recently, nanomaterial sorbents, such as carbon nanotubes, titania, silica, and clay polymer composites have received substantial attention due to their extraordinary performance in adsorbing pollutants from aqueous environments [16,17]. Ionic polymer clay nanocomposites [18] have shown an effective removal of inorganic and organic pollutants. The sorption capacity of polymer-clay composites is affected by the preparation process, type of polymer-clay composites, and application techniques, including membranes, nanofilters, and so on [19-24]. For all of these techniques and processes, the choice of polymer material is very important. Polymers can be water-soluble or water-insoluble, but in both cases, it is necessary to use functional polymers that may contain one or more coordination groups, ionizable groups, or groups with a permanent charge in the main chain or the side chain [20]. The functional polymers that exclusively possess groups that form complexes with metals, such as amines, carboxylic acids, amides, alcohols, amino acids, pyridines, or thioureas, are called complexing polymers [25]. The ability of these functional groups to interact with many metal ions can be provided by adding spacer groups or increasing the distance of the functional group from the main chain. Similarly, the water-soluble polymers can be a homo- or copolymers, and with an adequate selection of the comonomers, properties, such as the solubility, sorption capacity of metal ions, and selectivity, can be improved or controlled.

One of the more hazardous pollutants is arsenic (As). Thus, the contamination of groundwater, either from anthropogenic or natural sources with several impacts on society, has become a major environmental concern in different parts of the world. Millions of people in several countries are exposed to high levels of arsenic via the intake of arsenic-rich groundwater. Elevated levels of As in groundwater have been well documented in Chile, Mexico, China, Argentina, USA, and Hungary [26, 27] as well as in the Indian State of West Bengal, Bangladesh, and Vietnam [27-31]. Approximately 150 million people around the world are estimated to be affected globally, and the number is expected to increase as new affected areas are continuously discovered [32]. Arsenic, a wellknown carcinogen is considered to be one of the world's most hazardous chemicals [33]. The excessive and long-term (such as 5-10 years) human intake of toxic inorganic arsenic from drinking water and food may result in arsenicosis, skin cancers, internal cancers (bladder, kidney, and lung), diseases of the blood vessels of the legs and feet, diabetes, increased blood pressure, and reproductive disorders [34-36].

In terrestrial environments, the inorganic forms of arsenic, such as trivalent arsenite (III) and pentavalent arsenate (V) are generally more prevalent and toxic than the organic forms. Arsenic exerts detrimental effects on general protein metabolism with high toxicity by reacting with sulfhydryl groups in cysteine residues [37]. Elevated arsenic contamination in a region may result in societal stress, disability in individuals, poverty, and a decreased market value of potentially contaminated agricultural products, which leads to low income for affected farmers [38]. Applying the WHO provisional guidelines for drinking water of $10-50 \mathrm{ppb}$ of arsenic, a population of more than 100 million people worldwide is at risk, and of these, more than 45 million people, mainly in developing countries in Asia, are at risk of being exposed to more than $50 \mathrm{ppb}$ of As, which is the maximum concentration limit in drinking water in most Asian countries [32]. 
Currently, arsenic is estimated to affect more than 150 million people worldwide with its increasingly elevated concentrations in drinking water [39]. The major areas affected by arsenicosis have been reported to be large deltas and/or areas along major river basins across the world [40], such as in the Paraiba do Sul delta, Brazil [41], the Bengal delta [42-44], the Mekong delta, Cambodia [45], the Danube River basin, Hungary [46], the Hetao River basin, Mongolia [47], the Duero Cenozoic Basin, Spain [48], the Zenne River basin, Belgium [46], and Tulare Lake, USA [49]. The transfer of arsenic into the food chain will ultimately continue as a long-term risk to human and ecological systems [50]. Since water is the principal route through which arsenic enters the human body [51], an understanding of the processes of arsenic contamination in groundwater, the associated health risks, and the mitigation of arsenic is required [52].

Many treatment technologies, including chemical, physical, and biological processes, have been developed and refined to remove arsenic from water. Typical technologies for arsenic removal are a combination of chemical and physical processes, including sorption [53-64], oxidation [65-69], coagulation [70-73], membrane technologies [74-78], and combined ultrafiltration-sorption and oxidation-sorption methods [79-84].

The removal of arsenic from aqueous solutions using ultrafiltration assisted by a water-soluble polymer, also called the liquid-phase polymer-based retention (LPR) technique has been studied. In this technique, a water-soluble polymer is used as a polymeric extractant, and a ultrafiltration membrane is used as a filter [85]. The combination of a water-soluble polymer with ultrafiltration membranes could represent an alternative method for the removal of metal cations and oxyanions from aqueous media. The LPR technique possesses a series of advantages compared with other separation systems due to the process operating in a homogeneous medium that eliminates problems with diffusion in sorbent particles and avoids the mass transfer restrictions of the interface. The polymer can also be made to selectively interact with certain species of interest.

This review compiles and analyzes knowledge on the application of waterfunctional soluble polymers in conjunction with ultrafiltration membranes through the LPR technique to remove arsenic from aqueous solution.

\section{LPR TECHNIQUE TO REMOVE ARSENIC FROM WATER}

The separation and/or fractioning of inorganic species by membrane filtration with the aid of a water-soluble polymer are referred to as the LPR technique. In the LPR technique, a high molecular weight fraction of polymer (>100,000 Da) interacts with ions to form a new polymer-ion macromolecule, which is not able to pass through an ultrafiltration membrane. Poly(ether sulfone) or regenerated cellulose are commonly used as the ultrafiltration membrane material with a molecular size exclusion of $10,000 \mathrm{Da}$, which is much lower than the molecular weight of the water-soluble polymer sorbent.

\subsection{Washing Method}

To quantify the retention of metal ions or oxyanions, profiles of the retention percentage $(\% \mathrm{R})$ vs. the filtration factor $(\mathrm{Z})$ must be determined. The $\% \mathrm{R}$ is the fraction of ions that remain in the ultrafiltration cell (equation 1), $\mathrm{Mz}^{\mathrm{c}}$ is the absolute amount of ions in the feeding phase, and $\mathrm{Mz}^{\text {init }}$ is the absolute amount of ions at the beginning of the experiment.

$$
\% \mathrm{R}=\frac{\mathrm{Mz}^{\mathrm{c}}}{\mathrm{Mz}^{\text {init }}}
$$

The filtration factor $(\mathrm{Z})$, which corresponds to the ratio between the volume in the filtrate $\left(\mathrm{V}_{\mathrm{f}}\right)$ and the volume in the cell $\left(\mathrm{V}_{\mathrm{i}}\right)$, must be calculated according to equation 2.

$$
\mathrm{Z}=\frac{\mathrm{V}_{\mathrm{f}}}{\mathrm{V}_{\mathrm{i}}}
$$

\subsection{Enrichment method}

In the enrichment method, a polymer solution is concentrated with an anion solution until saturation is achieved. This method allows the calculation of the maximum polymer retention capacity.

The maximum retention capacity is defined as

$$
\mathrm{MRC}=\mathrm{MV} / \mathrm{Pm}
$$

where, $\mathrm{Pm}$ is the amount of polymer (g), $\mathrm{M}$ is the initial concentration of the ion $\left(\mathrm{mg} \mathrm{L}^{-1}\right)$, and $\mathrm{V}$ is the filtrate volume, which is defined as the volume passing through the membrane that is free of ions $(\mathrm{mL})$

\subsection{Functional water-soluble polymers}

In anion coordination chemistry, positively charged or neutral groups that are deficient in electrons can be used in anion complexation. Polyelectrolytes determine the structure of charged groups or ionizable groups as the type of ammonium group in aqueous solutions. Quaternary ammonium groups can create strong hydrogen bonds or form a neutral group in which a positive group $\mathrm{N}^{+}$can interact with anions. Interactions between inorganic species and polyelectrolytes are believed to be driven mainly by electrostatic forces. The advantages of these polymers in the synthesis process include the ease with which water-soluble polymers can be obtained, their short synthesis times and their low molecular weights. Water-soluble polymers are usually prepared via radical polymerization using vinyl monomers containing quaternary ammonium salt as side groups. These polymers are classified by their different molecular weights following washing in the ultrafiltration procedure by membranes corresponding to polyelectrolytes with active centers, and the presence of a polycation is necessary to retain an arsenic anionic group. In a single exchange reaction, an anionic group of the polyelectrolyte is replaced by a toxic anion from water and bound to a quaternary ammonium group. Only a single step in the mechanism of retention is needed by these structures.

Details of some of the more frequently studied water-soluble polymers structures are summarized in Table 1

Table 1. Water-soluble polymers, name, acronym and ion exchanger groups.

\begin{tabular}{|l|c|c|}
\hline Polymer & Acronym & $\begin{array}{c}\text { Ion exchanger } \\
\text { group }\end{array}$ \\
\hline $\begin{array}{l}\text { Poly[3-methacryloylamine)propyl) } \\
\text { trimethyl ammonium chloride }\end{array}$ & $\mathrm{P}(\mathrm{ClMPTA})$ & $\mathrm{Cl}^{-}$ \\
\hline $\begin{array}{l}\text { Poly[2-(acryloyloxy)ethyl] } \\
\text { trimethylammonium chloride }\end{array}$ & $\mathrm{P}(\mathrm{ClAETA})$ & $\mathrm{Cl}^{-}$ \\
\hline $\begin{array}{l}\text { Poly(ar-vinylbenzyl) } \\
\text { trimethylammonium chloride }\end{array}$ & $\mathrm{P}(\mathrm{ClVBTA})$ & $\mathrm{Cl}^{-}$ \\
\hline $\begin{array}{l}\text { Poly[2-(acryloyloxy)ethyl] } \\
\text { trimethylammonium methyl sulfate }\end{array}$ & $\mathrm{P}(\mathrm{SAETA})$ & $\left(\mathrm{OSO}_{3} \mathrm{CH}_{3}\right)^{-}$ \\
\hline $\begin{array}{l}\text { Poly(4-vinyl-1-methyl-pyridinium) } \\
\text { bromide }\end{array}$ & $\mathrm{P}(\mathrm{BrVMP})$ & $\mathrm{Br}^{-}$ \\
\hline $\begin{array}{l}\text { Poly[3-(methacryloylamino)propyl] } \\
\text { dimethyl (3-sulfopropyl) ammonium } \\
\text { hydroxide }\end{array}$ & $\mathrm{P}(\mathrm{HMPDSPA})$ & $\mathrm{OH}^{-}$ \\
\hline $\begin{array}{l}\text { Poly[(3-methacryloylamine)propyl) } \\
\text { trimethyl ammonium chloride-co- } \\
\text { acrylic acid] }\end{array}$ & $\mathrm{P}(\mathrm{ClMPTA}-$ co-AA) & $\mathrm{Cl}^{-}$and $\mathrm{H}^{+}$ \\
\hline
\end{tabular}

\subsection{Removal of arsenic by washing method}

\subsubsection{Effect of $\mathrm{pH}$ on arsenate retention}

In the LPR technique, $\mathrm{As}(\mathrm{V})$ is captured in mono- and divalent arsenate anions by synthesized structures. It has been reported in the literature that the inorganic species of $\mathrm{As}(\mathrm{V})$ coexist in equilibrium according to thermodynamic predictions:

$$
\begin{aligned}
& \mathrm{H}_{3} \mathrm{AsO}_{4}=\mathrm{H}^{+}+\mathrm{H}_{2} \mathrm{AsO}_{4}^{-} \quad \mathrm{pKa}_{1}=2.22 \\
& \mathrm{H}_{2} \mathrm{AsO}_{4}^{-}=\mathrm{H}^{+}+\mathrm{HAsO}_{4}^{-2} \quad \mathrm{pKa}_{2}=6.98 \\
& \mathrm{HAsO}_{4}={ }^{=}=\mathrm{H}^{+}+\mathrm{AsO}_{4}^{-3} \quad \mathrm{pKa}_{3}=11.53
\end{aligned}
$$

The simple washing method was applied for a range of acidic to basic $\mathrm{pH}$ values.

Figure 1 shows the retention profile of $\mathrm{As}(\mathrm{V})$ as a function of $\mathrm{pH}$ by $\mathrm{P}(\mathrm{CIMPTA})$. This profile shows the retention, $\mathrm{R}$ versus $\mathrm{Z}$, and the filtration factor. In general, $\mathrm{As}(\mathrm{V})$ was more easily retained at higher $\mathrm{pH}(6$ and 8$)$ values than at lower $\mathrm{pH}$ values. At a $\mathrm{pH}$ of 4 , when the reactivity is lower or the number of effective active sites of the homopolymer is low, the predominating species in solution are monovalent $\left(\mathrm{H}_{2} \mathrm{AsO}_{4}^{-}\right)$anions in equilibrium with the nondissociated acid. It is thought that the polarity of the functional group should be one controlling parameter of the exchange selectivity. At a $\mathrm{pH}$ of 6 , there is equilibrium between the monovalent $\left(\mathrm{H}_{2} \mathrm{AsO}_{4}{ }^{-}\right)$and divalent $\left(\mathrm{HAsO}_{4}{ }^{\circ}\right)$ anions in solution. It is suggested that the anionic exchanger prefers divalent anions compared to monovalent anions at the same medium conditions (acidic pH). 
This can be corroborated by the higher retention ability of the polymers in basic $\mathrm{pH}$ conditions when divalent species are predominant. The binding capacity of polymers is attributed to the anionic exchange between chloride anions and arsenate anions and the binding of these ions with the ammonium quaternary cationic group. This bond presumably forms between the nitrogen of the ammonium group, which is positively charged, and the oxygen of the arsenate anions, thus forming a dipole. The interaction is apparently not purely electrostatic and is presumably caused by the formation of ion-pairs between a covalently bonded partially movable functional group on the polymeric network and an oppositely charged anion. This pairing may be explained by waterstructure induced ion pairing [20], in which the larger and more polarizable ions disrupt the local water structure and more easily associate with a given quaternary ammonium ion. In this study of the washing method, As(V) is used in the polymer with a unique molar ratio of (20:1). The homopolymer can remove arsenic anions more selectively at a $\mathrm{pH}$ of 6 than at a $\mathrm{pH}$ of 8 , for which $\mathrm{HAsO}_{4}=$ predominates, with an output of $80-100 \%$. At a $\mathrm{pH}$ of 4 monovalent $\mathrm{H}_{2} \mathrm{AsO}_{4}$ species dominate, and the retention decreases to $40 \%$.

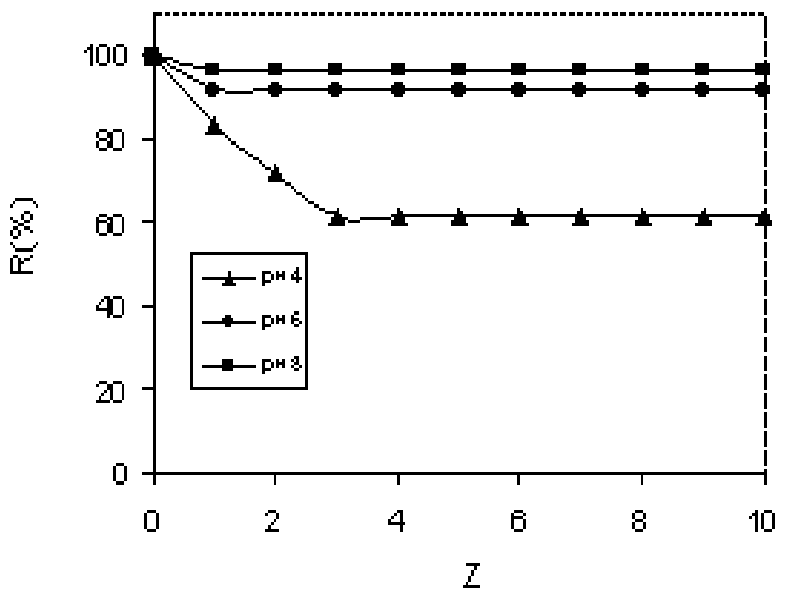

Figure 1. Retention profile of As(V) using poly[3-methacryloylamine)propyl) trimethyl ammonium chloride, (ClMPTA). Polymer amount: 2 mmol. As(V) ion amount: $0.1 \mathrm{mmol}$.

\subsubsection{Effect of the polymer:As(V) molar ratio on As removal}

An optimization study of $\mathrm{As}(\mathrm{V})$ retention was conducted using washing methods with poly[2-(acryloyloxy)ethyl]trimethylammonium chloride, $\mathrm{P}(\mathrm{ClAETA})$ and poly(ar-vinylbenzyl)trimethylammonium chloride, $\mathrm{P}(\mathrm{ClVBTA})$. The influences of polymer concentration, exposure time prior to filtration, and recovery of the activity of the polymers desorbing $\mathrm{As}(\mathrm{V})$ were assessed. In addition, studies of the performance of polymers on drinking water contaminated with $37 \mathrm{mg} / \mathrm{L}$ of As in several polymer:As(V) ratios were conducted.

Previous studies of $\mathrm{P}(\mathrm{ClVBTA})$ and $\mathrm{P}(\mathrm{ClAETA})$ have shown, in general, that $\mathrm{As}(\mathrm{V})$ species are more efficiently retained at higher $\mathrm{pH}$ values $(8$ and 6 compared to 4) for which divalent $\mathrm{HAsO}_{4}{ }^{=}$anions predominate and the number of effective active sites for the homopolymers is high. A study on the influence of the polymer or arsenic concentration in optimizing the reaction conditions was carried out. Solutions with polymer:As(V) molar ratios of (31:1), (20:1), (10:1), (6:1), and (3:1) were prepared. In general, a constant $7 \times 10^{-5}$ molar polymer concentration was used at $\mathrm{pH}$ values of 8 or 6 . The results of the washing method with $\mathrm{P}(\mathrm{ClVBTA})$ and $\mathrm{P}(\mathrm{ClAETA})$ at a constant ionic strength and at $\mathrm{pH} 8$ are presented in Figures 2 and 3, respectively. These retention profiles show the arsenic retention, $R$ versus $Z$.

Table 2 shows the retention profile $\mathrm{R}(\%)$ at a filtration factor of $\mathrm{Z}=10$. The retention capacity is limited by the concentration of polymers when the arsenic concentration is between 10-84 mg/L. For the two range orders of magnitude of $2 \times 10^{-4}$ and $7 \times 10^{-5}$ moles of polymer, a typical ratio of (20:1) was optimum. The high efficiency that the polycation maintains in the recovery of $\mathrm{As}(\mathrm{V})$ species is remarkable, even with stronger arsenic concentrations. The majority of authors have worked at or slightly above a limit of 0.05 or $1 \mathrm{mg} / \mathrm{L}$ for the removal of arsenic species from water.
The performance of $\mathrm{P}(\mathrm{ClVBTA})$ at a $\mathrm{pH}$ of 6 and $\mathrm{Z}=10$ for a characteristic polymer:As(V) molar ratio is shown in Figure 4 . The similarity of these results to those at a basic $\mathrm{pH}$ of 8 indicates that retention is more likely a function of the thermodynamic equilibrium of arsenate species than of conformational changes of the polymer structure in solution. Between $\mathrm{pH}$ values of 8 and $6, \mathrm{HAsO}_{4}{ }^{=}$and $\mathrm{HAsO}_{4}^{-2}$ coexist with one another.

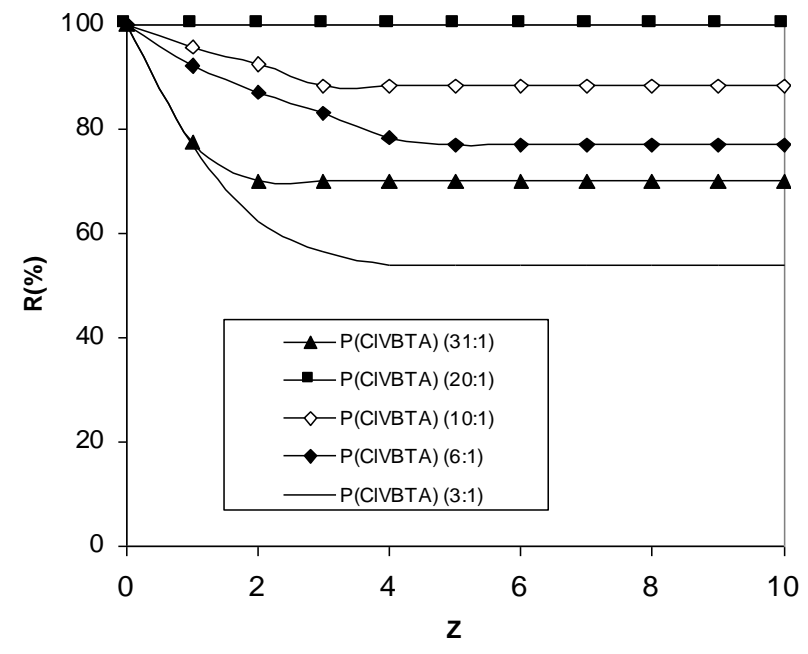

Figure 2. Retention profiles for $\mathrm{As}(\mathrm{V})$ at $\mathrm{pH} 8$ using $\mathrm{P}(\mathrm{ClVBTA})$. Polymer:As(V) molar ratio: $\Delta$ 31:1, 20:1, $\bullet$ 10:1, $\diamond$ 6:1. - 3:1.

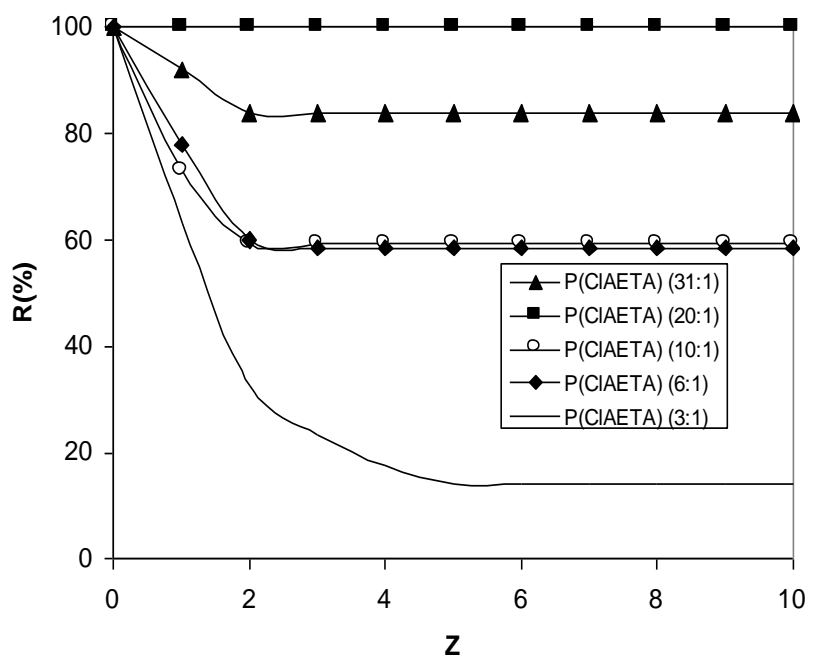

Figure 3. Retention profiles for $\mathrm{As}(\mathrm{V})$ at a $\mathrm{pH}$ of 8 using $\mathrm{P}(\mathrm{ClAETA})$. Polymer:As(V) molar ratio: $\Delta$ 31:1, 20:1, $\bullet$ 10:1, $\diamond$ 6:1 - - 3:1.

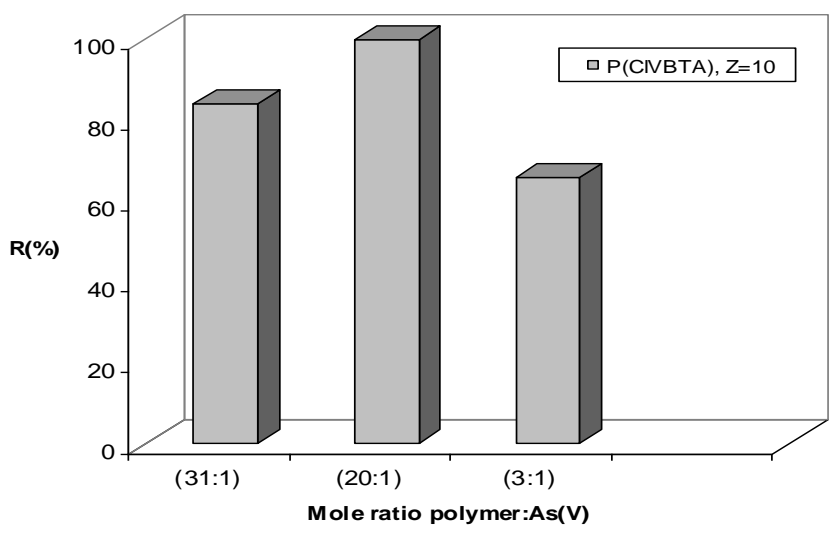

Figure 4. Retention profiles for $\mathrm{As}(\mathrm{V})$ using $\mathrm{P}(\mathrm{ClVBTA})$ at $\mathrm{pH} 6, \mathrm{Z}=10$, and different polymer:As(V) molar ratio. 
Table 2. Effect of the polymer:As(V) ratio on the retention of $\mathrm{As}(\mathrm{V})$ for the two water-soluble polymers $\mathrm{P}(\mathrm{ClVBTA})$ and $\mathrm{P}(\mathrm{ClAETA})$ at $\mathrm{pH} 8$.

\begin{tabular}{|c|c|c|c|c|}
\hline $\begin{array}{c}\text { Polymer:As(V) } \\
\text { molar ratio }\end{array}$ & $\begin{array}{c}\text { Mole of } \\
\text { polymer }\end{array}$ & $\begin{array}{c}\text { Mole of } \\
\text { As(V) }\end{array}$ & $\begin{array}{c}\text { P(CIVBTA) } \\
\text { R(\%) }\end{array}$ & $\begin{array}{c}\text { P(ClAETA) } \\
\text { R(\%) }\end{array}$ \\
\hline$(31: 1)$ & $7 \times 10^{-5}$ & $2.25 \times 10^{-4}$ & 70.0 & 84.0 \\
\hline$(20: 1)$ & $7 \times 10^{-5}$ & $3.45 \times 10^{-6}$ & 100.0 & 100.0 \\
\hline$(20: 1)$ & $2 \times 10^{-4}$ & $1.00 \times 10^{-5}$ & 100.0 & 100.0 \\
\hline$(10: 1)$ & $7 \times 10^{-5}$ & $6.90 \times 10^{-6}$ & 88.0 & 59.0 \\
\hline$(6: 1)$ & $7 \times 10^{-5}$ & $1.12 \times 10^{-5}$ & 77.0 & 60.0 \\
\hline$(3: 1)$ & $7 \times 10^{-5}$ & $2.25 \times 10^{-5}$ & 54.0 & 14.0 \\
\hline
\end{tabular}

\subsubsection{Effect of solution exposure time prior to filtration}

A study of the prior exposure time of $\mathrm{As}(\mathrm{V})$ in an aqueous polymer solution up to the (exchange-bond) species equilibrium was performed for $5 \mathrm{~min}, 15 \mathrm{~min}$, $30 \mathrm{~min}, 60 \mathrm{~min}, 4 \mathrm{~h}$, and $24 \mathrm{~h}$ of contact time before the ultrafiltration assays. These times did not include the time of ultrafiltration, which was a constant time of $200 \mathrm{~min}$ in all cases. $\mathrm{P}(\mathrm{ClVBTA})$ in a molar ratio of (20:1) at $\mathrm{pH} 8$ needs a short contact time of more than 15 min to reach the necessary equilibrium of 0.2 mmol of polymer in contact with $37 \mathrm{ppm}$ of $\mathrm{As}(\mathrm{V})$ and to maintain maximum retention. Nevertheless, for a polymer:As(V) ratio of (3:1) at a $\mathrm{pH}$ of 6 using 0.07 mmol of polymer, a selectivity of only $26 \%$ was reached for $4 \mathrm{~h}$ contact time. The maximum retention in the last case after $24 \mathrm{~h}$ of contact time was $66 \%$. For $\mathrm{P}(\mathrm{ClAETA}), 1 \mathrm{~h}$ of contact time is enough to reach equilibrium retention.

\subsubsection{Desorption of $\operatorname{As}(\mathrm{V})$}

To remove the retained arsenic $(\mathrm{V})$ from the polymer, the following experiment was performed. The polymer:As(V) solution was washed with water buffered at $\mathrm{pH} 2$ or 3. The ultrafiltration cell was used in a similar way to the washing method. The products of the assays with $\mathrm{P}(\mathrm{CIVBTA})$ in a polymer:As(V) ratio of (20:1) and $\mathrm{P}(\mathrm{ClVBTA})$ in a molar ratio or (31:1) at a $\mathrm{pH}$ of 8 were used. From the polymer recovery profile, it is possible to determine that recovery is near $95 \%$, which is considered very high (see Figure 5 , at $\mathrm{Z}=10$ ). We assume that the activity of the polymers is recovered and that strongly acidic conditions of the media did not significantly affect the active sites of the polymer. Therefore, acidic $\mathrm{pH}$ values of 3 and 2 were used in the radical polymer synthesis. In the future, it is necessary to propose an improvement to the assays to regenerate the polymer activity several times to continue the capture and desorbing of $\mathrm{As}(\mathrm{V})$.

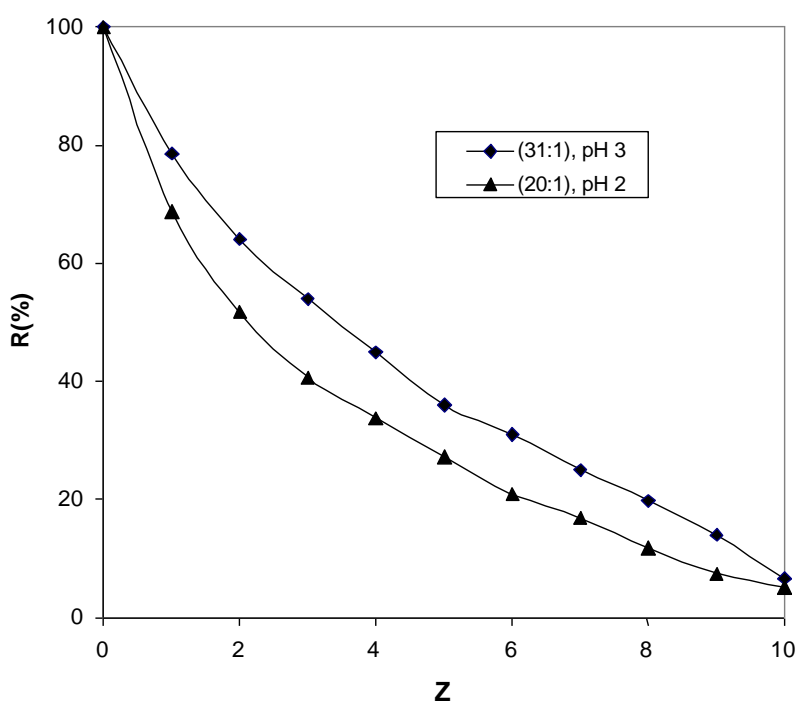

Figure 5. Removal profile of $\mathrm{As}(\mathrm{V})$ from $\mathrm{P}(\mathrm{ClVBTA})$ at $\mathrm{pH}$ values of 2 and 3 after assays of retention using (31:1) and (20:1) molar ratios of polymer:As(V) in basic $\mathrm{pH}$.

\subsubsection{Effect of competitive monovalent and divalent anions}

The polycationic exchanger maintains the highest retention of arsenate species in the absence of other anions. Assays of arsenic retention in the presence of the divalent anions $\mathrm{SO}_{4}^{-2}$, or $\mathrm{HPO}_{4}^{-2}$ at $\mathrm{pH} 8$ by the washing method are summarized in Table 3. Molar ratios of $\mathrm{As}(\mathrm{V}): \mathrm{S}(\mathrm{VI})$ or $\mathrm{As}(\mathrm{V}): \mathrm{P}(\mathrm{V})$ of $(1: 1)$ and of polymer:As(V) of (20:1) were used, with $37.5 \mathrm{ppm}$ of arsenic and $2 \mathrm{~g} / \mathrm{L}$ of $\mathrm{P}(\mathrm{ClVBTA})$ in the feed. It is reasonable to assume that the $\mathrm{SO}_{4}{ }^{-2}$ or $\mathrm{HPO}_{4}^{-2}$ anions competitively adsorb to the same active sites on the polymer because the tetrahedral structures of $\mathrm{SO}_{4}{ }^{-2}$ and $\mathrm{HPO}_{4}{ }^{-2}$ are equivalent to those of $\mathrm{HASO}_{4}{ }^{-2}$. However, the results show that nearly $86 \%$ of arsenic was retained by the polymer, depending on the use of a high mass polymer. The investigation was continued by studying the effects of those anions on the retention capacity of arsenate that might be present in drinking water. Then, the $\mathrm{P}(\mathrm{ClVBTA})$ polycation was used with drinking water contaminated by the addition of $37 \mathrm{ppm}$ of $\mathrm{As}(\mathrm{V})$. The purpose was to determine if the presence of an excess of others ions, mainly $\mathrm{SO}_{4}{ }^{-2}(120 \mathrm{mg} / \mathrm{L})$, would cause a change in the retention ability of natural systems. The composition of ground water shows the presence of $\mathrm{SO}_{4}{ }^{-2}$, $\mathrm{S}^{-2}, \mathrm{~F}^{-}$, and $\mathrm{Cl}^{-}$anions. Ultrafiltration with the washing method was applied in several assays with polymer:As(V) molar ratios of (20:1), (40:1), and (60:1), and the drinking water was buffered at a $\mathrm{pH}$ of 8 using $\mathrm{NaOH}$ as the electrolyte. Tables 3 and 4 show the arsenic retention properties of $\mathrm{P}(\mathrm{ClVBTA})$. Even in the absence of arsenic in the filtrate, the retention rate was approximately $83 \%$ for the different molar ratios. The approach was similar to that using natural media with drinking water at a $\mathrm{pH}$ of 7.14. The retention profile was similar with a small percentage of arsenic in the filtrate. It is concluded that the differences in the buffered and un-buffered drinking water solutions did not influence the retention properties.

Table 3. Effect of the presence of sulphate and phosphate as interferents on the arsenic retention of $\mathrm{P}(\mathrm{ClVBTA})$, polymer:As(V) molar ratio: 20:1.0, $\mathrm{pH} 8$

\begin{tabular}{|c|c|c|c|c|c|}
\hline $\begin{array}{c}\text { Polymer:As(V) } \\
\text { mole ratio }\end{array}$ & $\begin{array}{c}\text { As(V) in } \\
\text { the feed } \\
(\mathbf{m o l} / \mathbf{L})\end{array}$ & $\begin{array}{c}\text { As(V) on } \\
\mathbf{P}(\mathbf{C l V B T}) \\
(\mathbf{m o l} / \mathbf{L})\end{array}$ & $\begin{array}{c}\text { Arsenic in } \\
\text { filtrate } \\
(\mathbf{m o l} / \mathbf{L})\end{array}$ & $\begin{array}{c}\mathbf{S O}_{4}^{-2} \\
\text { in the feed } \\
(\mathbf{m o l} / \mathbf{L})\end{array}$ & $\begin{array}{c}\mathbf{H P O}_{4}^{-2} \\
\text { in the feed } \\
(\mathbf{m o l} / \mathbf{L})\end{array}$ \\
\hline$(20: 1)$ & $5 \times 10^{-4}$ & $4.32 \times 10^{-4}$ & 0.0 & $5 \times 10^{-4}$ & --- \\
\hline$(20: 1)$ & $5 \times 10^{-4}$ & $4.00 \times 10^{-4}$ & 0.0 & --- & $5 \times 10^{-4}$ \\
\hline$(20: 1)$ & $5 \times 10^{-4}$ & $4.00 \times 10^{-4}$ & 0.0 & $5 \times 10^{-4}$ & $5 \times 10^{-4}$ \\
\hline
\end{tabular}

Table 4. Assays with drinking water buffered at $\mathrm{pH} 8$ over $\mathrm{P}(\mathrm{ClVBTA})$.

\begin{tabular}{|c|c|c|c|c|}
\hline $\begin{array}{c}\text { Polymer:As(V) } \\
\text { mole ratio }\end{array}$ & $\begin{array}{c}\text { Polymer } \\
(\mathrm{g} / \mathrm{L})\end{array}$ & $\begin{array}{c}\text { As(V) } \\
\text { in the feed } \\
(\mathbf{m o l} / \mathbf{L})\end{array}$ & $\begin{array}{c}\text { As(V) on } \\
\mathbf{P}(\mathbf{C I V B T A}) \\
(\mathbf{m o l} / \mathbf{L})\end{array}$ & $\begin{array}{c}\text { Arsenic in } \\
\text { the filtrate } \\
(\mathbf{m o l} / \mathbf{L})\end{array}$ \\
\hline$(60: 1)$ & 6 & $4.938 \times 10^{-4}$ & $4.07 \times 10^{-4}$ & 0.0 \\
\hline$(40: 1)$ & 4 & $4.938 \times 10^{-4}$ & $3.96 \times 10^{-4}$ & 0.0 \\
\hline$(20: 1)$ & 2 & $4.938 \times 10^{-4}$ & $3.56 \times 10^{-4}$ & 0.0 \\
\hline
\end{tabular}

2.4.6 Polycation-polyanion complex in aqueous solution and its effect on arsenic retention

The formation of polyelectrolyte complexes is governed by the characteristics of the individual polyelectrolyte components, including the properties of the ionic sites, such as the strength or weakness of the electrolyte, the position of cationic sites, the charge density, the rigidity of macromolecular chains, and the chemical environment (solvent type, ionic strength, $\mathrm{pH}$, and temperature).

Studies of the concerted action of water-soluble copolymers having anionic and cationic ion-exchange sites for the retention of $\mathrm{As}(\mathrm{V})$ from an aqueous media are presented. The results for copolymer poly[(3-methacryloylamine) propyl) trimethylammonium chloride-co-acrylic acid], $\mathrm{P}(\mathrm{ClMPTA}-\mathrm{co}-\mathrm{AA})$ prepared in cation:anion molar ratios of (1:1), (1:2), (2:1), and (4:1) show that the retention behavior for arsenic anions depended strongly on the $\mathrm{pH}$, polymer concentration, and copolymer composition. 
The actions of the polycations and polyanions of a copolymer versus the $\mathrm{pH}$ and its arsenic retention capacity are shown in Figures 6, 7, and 8. At a molar feed ratio of $1: 1$, the copolymer loses its ability to bind the anion independently of the $\mathrm{pH}$. Based on the literature, a pendant-type polycation can form an equimolar complex with a polyanion (reference).

This fact can be explained by an interaction between the $\mathrm{COO}^{-}$group from the $\mathrm{P}(\mathrm{AA})$ with the $-\mathrm{N}^{+}\left(\mathrm{R}_{3}\right)$ groups of $\mathrm{P}(\mathrm{ClMPTA})$ by charge transfer, which should block both functional groups.

It is known that $\mathrm{P}(\mathrm{AA})$ is a proton donating polymer, but its complexation with polycations of another depends not only on the composition of each polycation in the copolymer but also on the $\mathrm{pH}$ of the aqueous solution. The dissociation of $\mathrm{P}(\mathrm{AA})$ is increased in the presence of $\mathrm{P}(\mathrm{ClMPTA})$. At $\mathrm{pH}$ values lower than 4 (beyond a pka $=5.6$ ), the degree of dissociation of $\mathrm{P}(\mathrm{AA})$ is decreased. Crosslinking by both hydrogen bonding and covalent bonds between polycations and polyanions inhibits the function of copolymers by the retention of anions regardless of the molar ratio being 1:2 or 2:1, as shown in Figures 7 and 8, respectively. It is assumed that complexes form between both monomer units. This is the form because the arsenate retention is negligible. At $\mathrm{pH} 6$, most carboxylic acid groups of $\mathrm{P}(\mathrm{AA})$ exist as carboxylate anion groups and, therefore, are able to participate in the formation of complexes. Such conditions cannot be completely satisfied. It has been reported that the reactivity of a polyanion chain covered by polycations may be considered to be higher than that of a free chain, likely due to the changes of conformation, dissociation and microenvironment in the domain of the polymer chain. Therefore, completely neutralized polyelectrolyte complexes and completely free polyelectrolytes coexist in the solution. In our case, it is suggested that a portion of the extra active sites are dissociated by the extraction of protons from the aqueous solution without being incorporated into the domain of the polymer chains. Therefore, a large portion of the quaternary ammonium groups are free and available to bind with arsenate in the solution when the molar ratio of the copolymer composition is not equimolar. This effect is higher when the ratio of polycation/polyanion $>1$, and a large portion of $-\mathrm{N}^{+}\left(\mathrm{CH}_{3}\right)_{3}$ is free to interact with arsenate anions, increasing the retention ability, as can be observed in the profile of Figure 8. At $\mathrm{pH} 8$, the retention of arsenate ions increases for both copolymers without an equimolar ratio up to $30 \%$ for $\mathrm{Z}=10$. It is shown that by increasing the number of the quaternary ammonium groups in the copolymers, the retention capacity is enhanced. At a molar ratio of (4:1), the profile is similar to that of pure $\mathrm{P}(\mathrm{ClMPTA})$ (see Figure 9). The performance of pure $\mathrm{P}(\mathrm{AA})$ was found to be negligible in the retention of arsenate anions, independently of the $\mathrm{pH}$ of the media (see Figure 10).

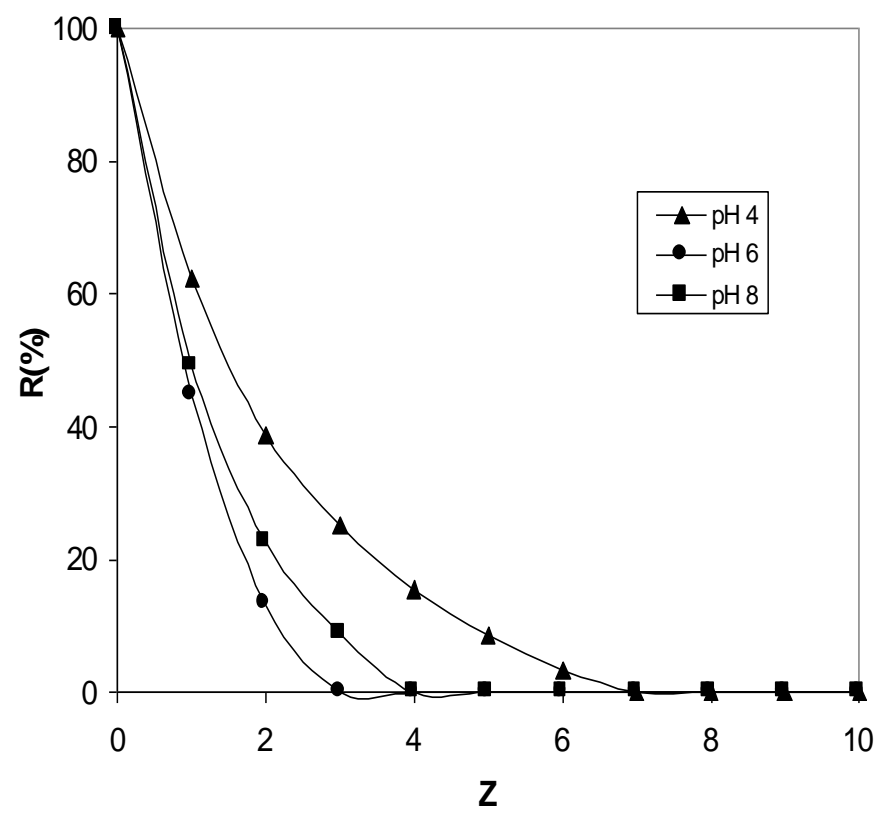

Figure 6. Retention profile of $\mathrm{As}(\mathrm{V})$ for poly[(3-methacryloylamine)propyl) trimethyl ammonium chloride-co-acrylic acid], $\mathrm{P}(\mathrm{ClMPTA}-c o-\mathrm{AA}),(1: 1)$. Polymer amount: $0.2 \mathrm{mmol}$. Absolute $\mathrm{As}(\mathrm{V})$ ion: $0.01 \mathrm{mmol}$.

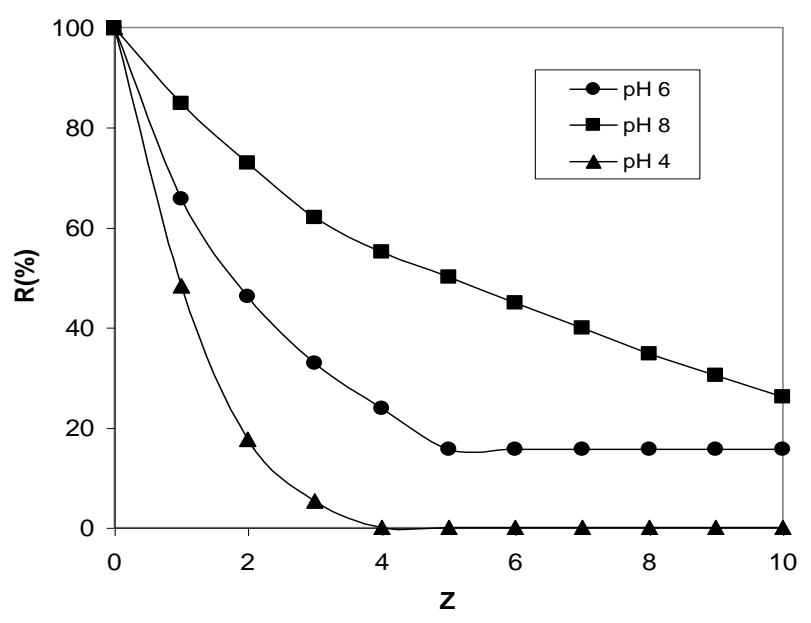

Figure 7. Retention profile of $\mathrm{As}(\mathrm{V})$ for poly[(3 methacryloylamine)propyl) trimethylammonium chloride-co-acrylic acid], P(ClMPTA-co-AA), (1:2). Polymer amount: $0.2 \mathrm{mmol}$. Absolute As(V) ion: $0.01 \mathrm{mmol}$.

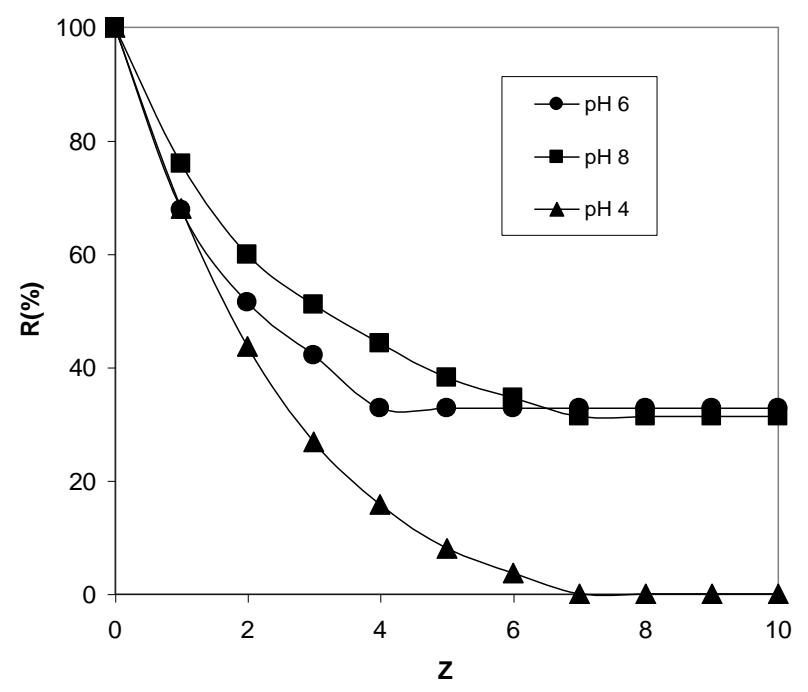

Figure 8. Retention profile of $\mathrm{As}(\mathrm{V})$ for poly[(3-methacryloylamine)propyl) trimethyl ammonium chloride-co-acrylic acid], P(CIMPTA-co-AA), (2:1). Polymer amount: $0.2 \mathrm{mmol}$. Absolute As(V) ion: $0.01 \mathrm{mmol}$.

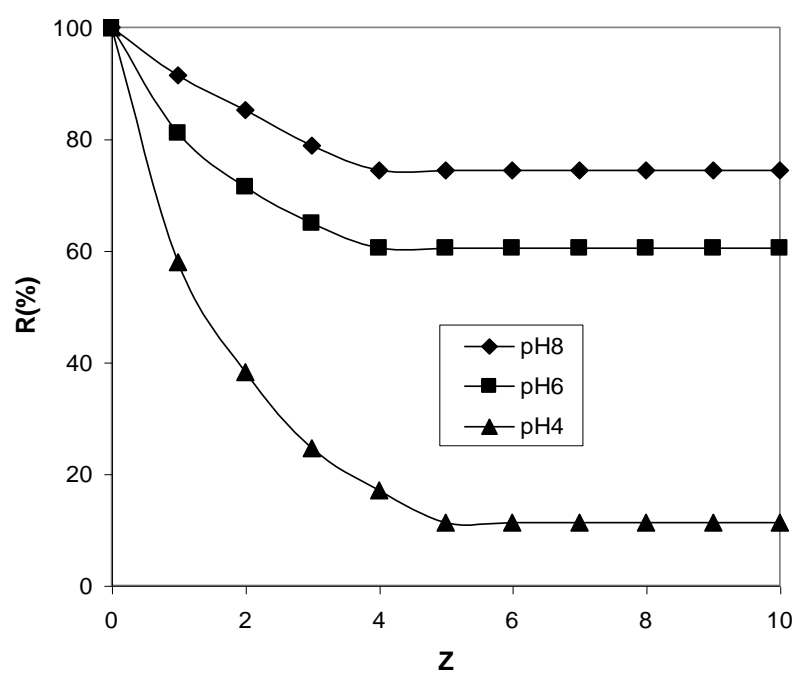

Figure 9. Retention profile of $\mathrm{As}(\mathrm{V})$ for poly[(3-methacryloylamine)propyl) trimethyl ammonium chloride-co-acrylic acid], P(CIMPTA-co-AA), (4:1). Polymer amount: $0.2 \mathrm{mmol}$. Absolute $\mathrm{As}(\mathrm{V})$ ion: $0.01 \mathrm{mmol}$ 


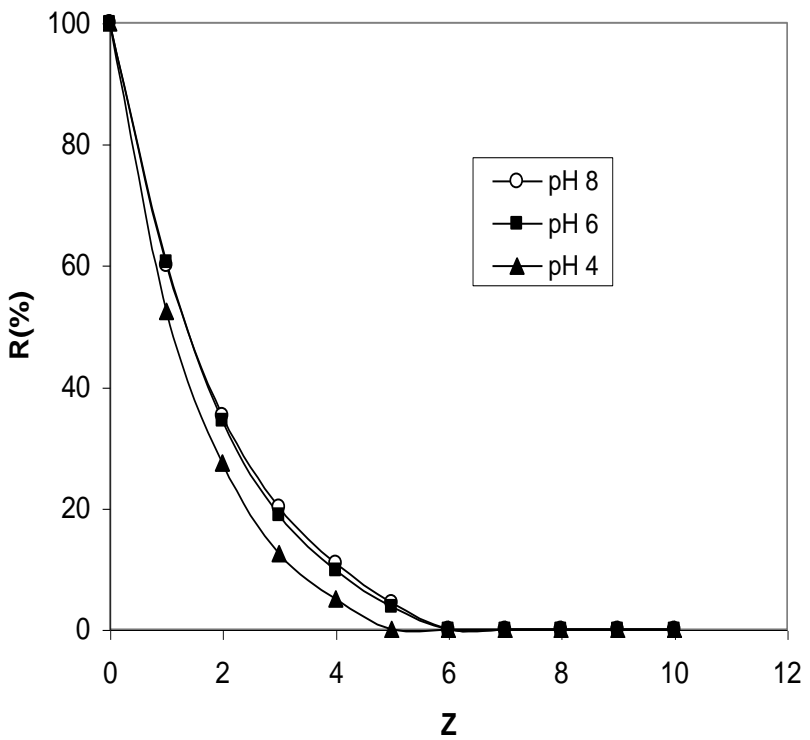

Figure 10. Retention profile of As(V) for poly(acrylic acid), P(AA). Polymer amount: $0.2 \mathrm{mmol}$. Absolute As(V) ion: $0.01 \mathrm{mmol}$.

\subsubsection{Influence of anion exchanger of polymer on arsenic retention}

A global study of polyelectrolyte quaternary ammonium salts demonstrated differences in selectivity according to the nature of the anionic exchanger group molecules of $\mathrm{Cl}^{-}, \mathrm{OH}^{-}, \mathrm{Br}^{-}$, and $\left(\mathrm{OSO}_{3} \mathrm{CH}_{3}\right)^{-}$. However, all polymers were more effective at $\mathrm{pH}$ values of 8 and 6 than at a $\mathrm{pH}$ of 4 , and the nature of the quaternary ammonium group influences the retention properties.

The most remarkable selectivity was shown in those polyelectrolytes with exchanger chloride anions, such as poly[3(methacryloylamine)propyl]trimethylammonium chloride, P(CIMPTA), poly[2(acryloyloxy)ethyl]trimethylammonium chloride (ClAETA) and poly(arvinylbenzyl)trimethylammonium chloride $\mathrm{P}(\mathrm{ClVBTA})$ compared to poly(4vinyl-1-methyl-pyridinium)bromide, $\quad \mathrm{P}(\mathrm{BrVMP}) ; \quad$ poly[2(acryloyloxy)ethyl]trimethylammonium methyl sulfate, P(SAETA), and poly[3(methacryloylamino)propyl]dimethyl(3-sulfopropyl) ammonium hydroxide, $\mathrm{P}$ (HMPDSPA). The retention profiles are similar to those of exchanger-chloride group polymers, and the highest yield of $100 \%$ was obtained at basic and neutral $\mathrm{pH}$ values for $\mathrm{P}(\mathrm{ClMPTA})$ and $\mathrm{P}(\mathrm{ClVBTA})$ (see Figures 1 and 11). A comparative study between synthesized polymers and commercial $\mathrm{P}(\mathrm{ClBVTA})$ (see figure 11) showed no differences in retention ability. The polymer binding capacity could be attributed to the anionic exchange between the polymers' anionic groups and the arsenate anions and the binding of the latter with the ammonium quaternary cationic group. This behavior is attributed to the ease with which the quaternary ammonium group releases $\mathrm{Cl}^{-}$anions compared to $\mathrm{OH}^{-}$or $\mathrm{CH}_{3} \mathrm{OSO}_{3}{ }^{-}$in solution. The larger and more polarizable the ion is, the greater the disruption produced in the local water structure is and the more easily it associates with given quaternary ammonium ions [25]. Specifically, polarizable monovalent ions will be retained longer in comparison to chloride due to the greater hydrophobicity of the anion-exchange site, with a higher capacity at a given hydrophobicity [26]. For halogens, it has been reported [27] that when the electronegativity decreases in the following order $\mathrm{F}>\mathrm{Cl}>\mathrm{Br}>\mathrm{I}$, the exchange capacity increases over the $\mathrm{P}(\mathrm{ClVBTA})$ resin. The higher selectivity of nearly 95 $\%$ exhibited by $\mathrm{P}(\mathrm{BrVMP})$ at basic $\mathrm{pH}$ values could be attributed to the effect on the structure by aryl ammonium quaternary ions and the role of bromide ions (see Figure 12). Alkyl ions are a stronger base than pyridinium ions, and its conjugate, quaternary ammonium ions, are a weaker acid. Conversely, as the quaternary ammonium ion becomes larger, it more easily forms the water structure-induced ion pair with hydroxide, and in this form, the polymer's retention capacity for arsenate anions will be diminished (see Figure 9). A high and remarkable difference in selectivity was presented by the same structures and different quaternary ammonium groups and anionic exchanger groups, as was the case for the $\mathrm{P}(\mathrm{CIMPTA})$ and $\mathrm{P}(\mathrm{HMPDSPA})$ polymers (see Figure 1 and 13). At basic $\mathrm{pH}$ values, the highest yield of P(CIMPTA) decreased to nearly $30 \%$ for P(HMPDSPA).

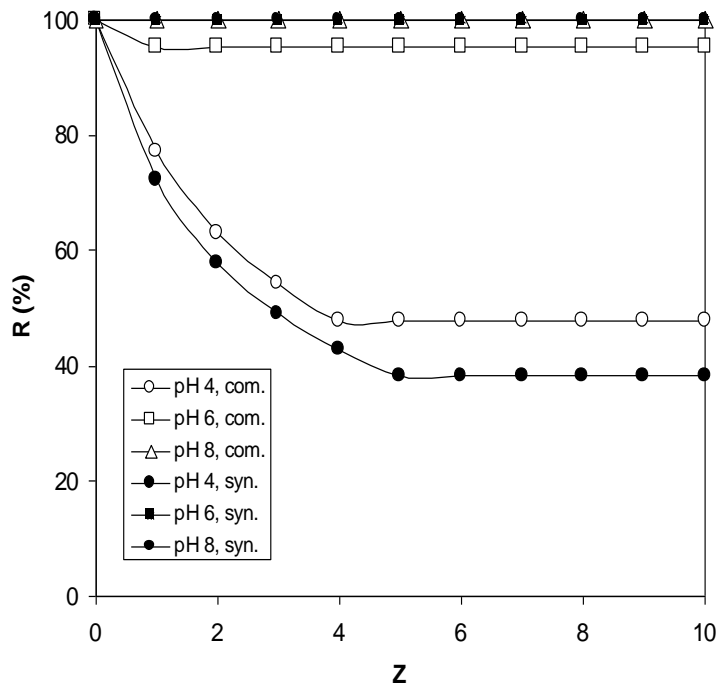

Figure 11. Retention profiles for $A s(V)$ by using poly[ar-vinylbenzyl] trimethyl ammonium chloride, $\mathrm{P}(\mathrm{ClVBTA})$. Absolute polymer amount: 0.2 mmol. Absolute As(V) ion: $0.01 \mathrm{mmol}$. Synthesized polymer (open circle) and commercial polymer (full circle).

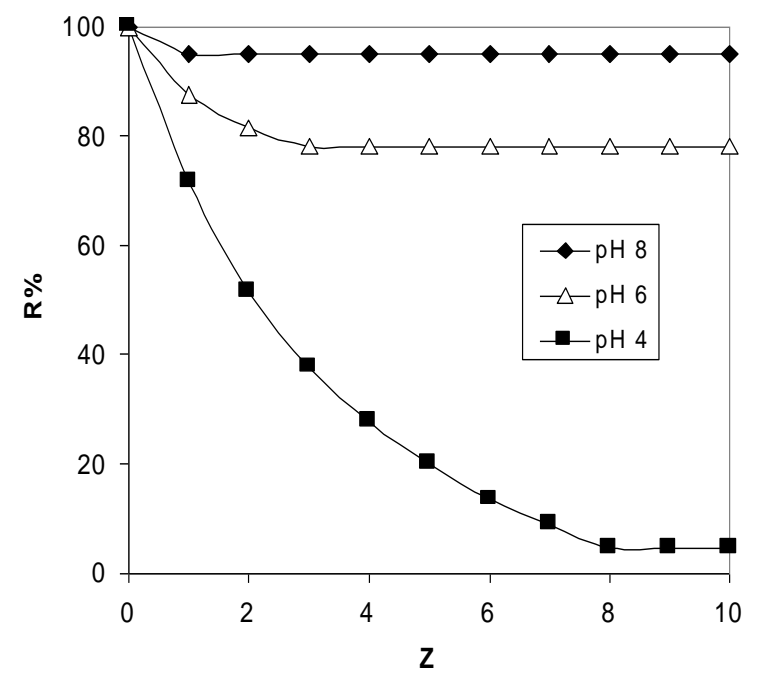

Figure 12. Retention profiles of $\mathrm{As}(\mathrm{V})$ by using poly[4-vinyl-1-methylpyridinium] bromide, $\mathrm{P}(\mathrm{BrVMP})$. Absolute polymer amount: $0.2 \mathrm{mmol}$. Absolute As(V) ion: $0.01 \mathrm{mmol}$.

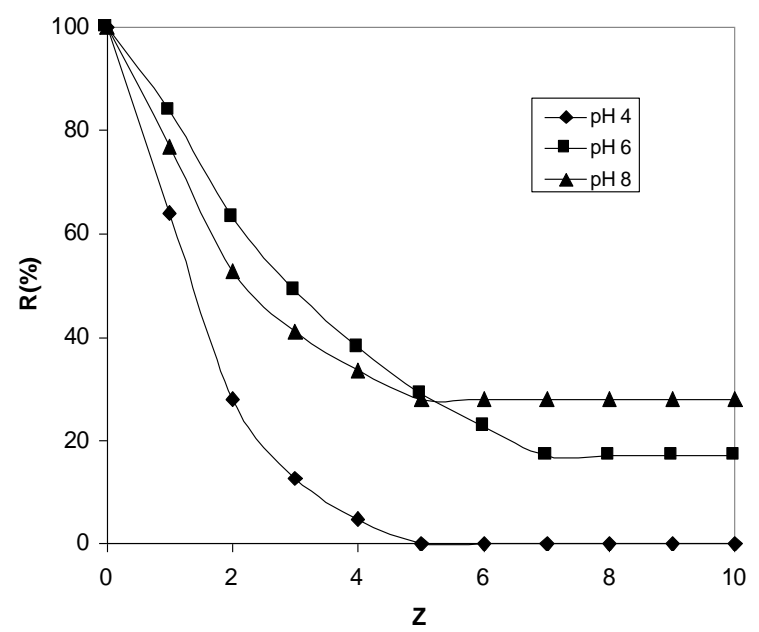

Figure 13. Retention profiles for As(V) by using poly[3-methacryloylamine) propyl]dimethyl(sulfate propyl) ammonium]hydroxide, P(HMPDSPA). Absolute polymer amount: $0.2 \mathrm{mmol}$. Absolute $\mathrm{As}(\mathrm{V})$ ion: $0.01 \mathrm{mmol}$. 


\subsubsection{Removal of arsenic by enrichment method}

The results of the assays performed with $\mathrm{P}(\mathrm{ClAETA})$ using the enrichment method to determine the maximum retention capacity (MRC) for arsenic anions in aqueous solutions at a $\mathrm{pH}$ of 8 are shown in Figure 14. In similar conditions, the MRC was calculated as $142 \mathrm{mg} / \mathrm{g}$ by $\mathrm{P}(\mathrm{ClAETA})$ and $75 \mathrm{mg} / \mathrm{g}$ by P(SAETA), corresponding to a total filtrate volume of $300 \mathrm{~mL}$.

Assuming a quantitative retention of $\mathrm{As}(\mathrm{V})$, the enrichment factors $(\mathrm{E}=3.5$ for $\mathrm{P}(\mathrm{ClAETA})$ and $\mathrm{E}=2.5$ for $\mathrm{P}(\mathrm{SAETA})$ ) were determined. This type of anionic exchanger group was found to be an important factor in arsenate retention. For the $\mathrm{P}(\mathrm{ClMPTA})$ homopolymer, the $\mathrm{MRC}$ was calculated as 117 $\mathrm{mg} / \mathrm{g}$, corresponding to a total filtrate volume of $300 \mathrm{~mL}$.

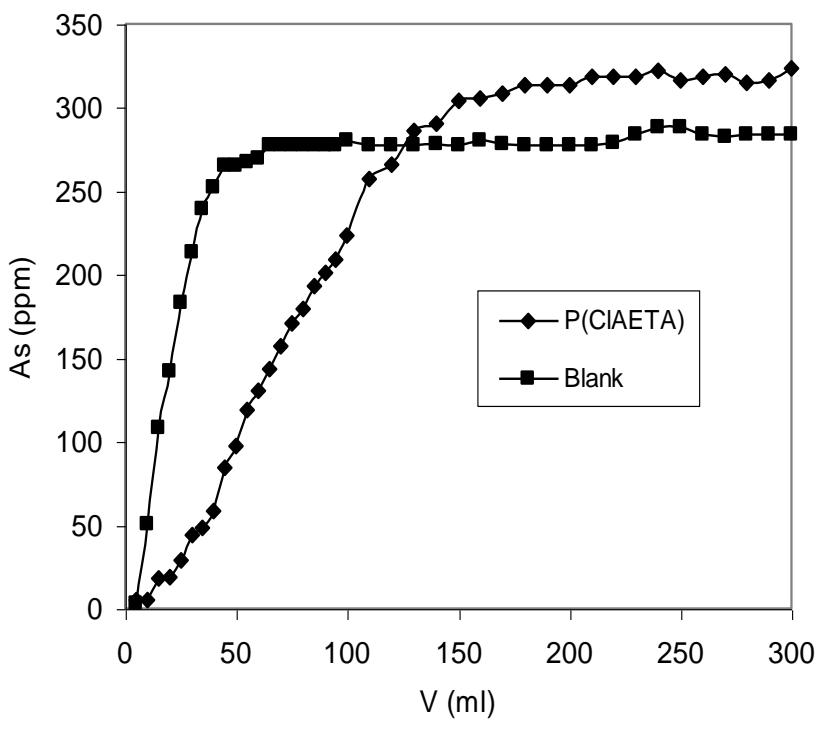

Figure 14. Maximum retention capacity (MRC) of poly[2-(acryloyloxy)ethyl] trimethylammonium chloride, $\mathrm{P}(\mathrm{ClAETA})$ at $\mathrm{pH} 8.0 .8 \mathrm{mmol}$ of polymer and 4 $\mathrm{mM}$ of $\mathrm{As}(\mathrm{V})$

The maximum retention capacity (MRC) of poly[ar-vinylbenzyl]trimethyl ammonium chloride, $\mathrm{P}(\mathrm{ClVBTA})$ was evaluated with drinking water at a $\mathrm{pH}$ of 7.14 in a more diluted $(0.5 \mathrm{mM} \mathrm{As}(\mathrm{V}))$ solution. The profile is shown in Figure 15. The calculated value, as $\mathrm{mg} / \mathrm{g}$ corresponding to a total filtrate volume 300 $\mathrm{ml}$, was $157 \mathrm{mg} / \mathrm{g}$. The enrichment factor $€$, a measure of the binding capacity of a polymer, was 8 for $\mathrm{P}(\mathrm{ClVBTA})$.

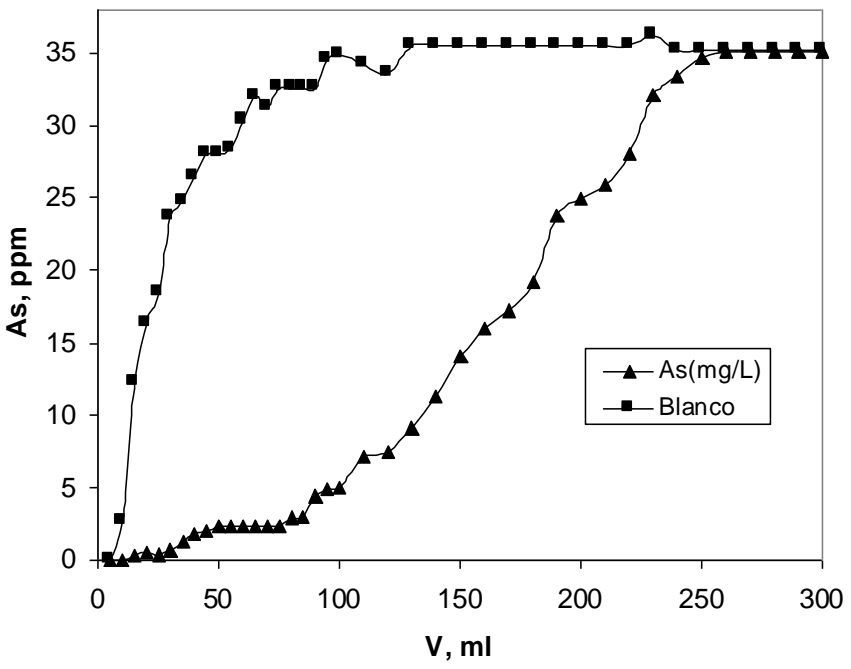

Figure 15. Maximum retention capacity (MRC) for poly[ar-vinylbenzyl] trimethyl ammonium chloride, $\mathrm{P}(\mathrm{ClVBTA})$, in drinking water at the $\mathrm{pH}$ of water itself. $0.2 \mathrm{mmol}$ of polymer and $0.5 \mathrm{mM}$ of $\mathrm{As}(\mathrm{V})$.

\subsection{Electro-oxidation (EO) of $\mathrm{As}(\mathrm{III})$ and recuperation of $\mathrm{As}(\mathrm{V})$ by LPR}

The detection of different forms of arsenic in industrial, biological and environmental media has received increasing attention in recent years. There are several analytical methods for inorganic arsenic in water [30]. The use of electrochemical methodologies has recently come to the forefront of research as a possible means to develop light, rapid and efficient sensing devices. A widely used technique for determining arsenic is anodic or cathodic stripping voltammetry, especially with mercury, solid gold, gold film and iridium oxide film electrodes [31-32].

Moreover, the tremendous environmental impact of these highly toxic contaminating agents has prompted the scientific community to find appropriate technologies for the removal of trace arsenic from drinking water, wastewater and industrial effluents. Arsenic occurs in a variety of forms and oxidation states, and the redox- and $\mathrm{pH}$-controlled diversity of arsenic species in water results in complex selectivity issues that have not yet fully been addressed [33]. The complete extraction of arsenic, especially As(III), which is more difficult to remove than As(IV), still represents a true challenge.

The goal is to selectively separate arsenic species by liquid-phase retention assisted by polymers (LPR-P technique) by combining the selective adsorption properties of cationic water-soluble polymers with remarkable retention properties towards As(V) oxo-anionic species with the electrocatalytic oxidation of As(III) into its more easily removable analogue As(V). The use of polycationic materials to produce an electrostatic interaction with the negatively charged toxic species of $\mathrm{As}(\mathrm{V})$ has been proposed.

The common cationic water-soluble polymers used as supporting electrolytes in the electro-oxidation of arsenic and in the retention of $\mathrm{As}(\mathrm{V})$ species were P(CIMPTA), P(CIMPTA-co-AA), P(CIVBTA), and P(ClAETA).

The main objective was to evaluate the possibility of using chelating watersoluble poly(quaternary ammonium) salts as supporting electrolytes in the electrocatalytic oxidation of $\mathrm{As}(\mathrm{III})$ to $\mathrm{As}(\mathrm{V})$ species, from cyclic voltammetry and electrolysis experiments performed with iridium-oxide-film-modified carbon electrodes and ruthenium oxide.

\subsubsection{Iridium-oxide-modified carbon electrodes}

Iridium-oxide-film-modified carbon electrodes were prepared by oxidation at a constant potential or by cycling in a solution of $\mathrm{K}_{3} \mathrm{IrCl}_{6}$. The iridium-oxidemodified electrodes showed a good reversibility and stability for weeks.

Preliminary results for the electrocatalytic oxidation at $0.6-0.8 \mathrm{~V}$ of $\mathrm{As}$ (III) in solutions containing different chelating polyammonium soluble polymers as the supporting electrolyte and with iridium-oxide-film-modified carbon disc microelectrodes ( $3 \mathrm{~mm}$ diameter) showed a catalytic effect with the addition of As(III). The cathodic peak current disappeared, and one anodic peak current, Ipa, is proportional to the arsenic concentration. The catalytic current, Icat, is determined as $\left(\mathrm{Ipa}-\mathrm{Ip}_{0}\right.$ ), and $\mathrm{Ip}_{0}$ is the current without arsenic (see Figure 16 curve a). There is a good linearity of the catalytic oxidation current in the 0.1 $\mathrm{mM}$ to $3 \mathrm{mM} \mathrm{As}$ (III) concentration range, as shown in Figure 16 curve b. The addition of $1 \mathrm{mM}$ As(III) to the unbuffered homo-polyelectrolytes of 0.01 and $0.2 \mathrm{M}$ solutions did not induce important changes in the arsenic oxidation potential, while changing the $\mathrm{pH}$ from 3 to 9 did. Different effects were found with the unbuffered $\mathrm{P}(\mathrm{ClMPTA}-\mathrm{co}-\mathrm{AA})$ copolymer solution (synthesized polycation:polyanion molar ratio of (1:1)), maintaining a constant $\mathrm{pH}$ and an oxidation potential of up to $3 \mathrm{mM}$ As(IIII).

The electrocatalytic oxidation of As(III) species was also performed at the preparative scale with the iridium oxide film modified with the carbon felt electrodes (10 mm diameter, $4 \mathrm{~mm}$ thick). The residual concentration of As(III) was monitored with an analytically modified carbon microelectrode (see Figure $17 \mathrm{a}$ and $\mathrm{b}$ ). In these experimental conditions, the molar conversion of As(III) to As(V) was $99 \%$, which is near the total theoretical charge. Assays with the ultrafiltration technique showed that for a polymer:As(V) molar ratio of (20:1) and $0.5 \mathrm{mM} \mathrm{As}(\mathrm{III})$ in the feed, the oxidation and recuperation of arsenic was $100 \%$ with $\mathrm{P}(\mathrm{ClVBTA}), \mathrm{P}(\mathrm{BrVMP})$, and $\mathrm{P}(\mathrm{ClMPTA})$ at a $\mathrm{pH}$ of 8 . Figure 18 shows the retention profile after the electrolysis of As(III) on the iridiummodified felt carbon electrode in a $\mathrm{P}(\mathrm{ClVBTA})$ solution with a $\mathrm{pH}$ of 8 and polymer:As(III) molar ratios of (20:1) and (55:1) for $0.5 \mathrm{mM} \mathrm{As(III).}$ 


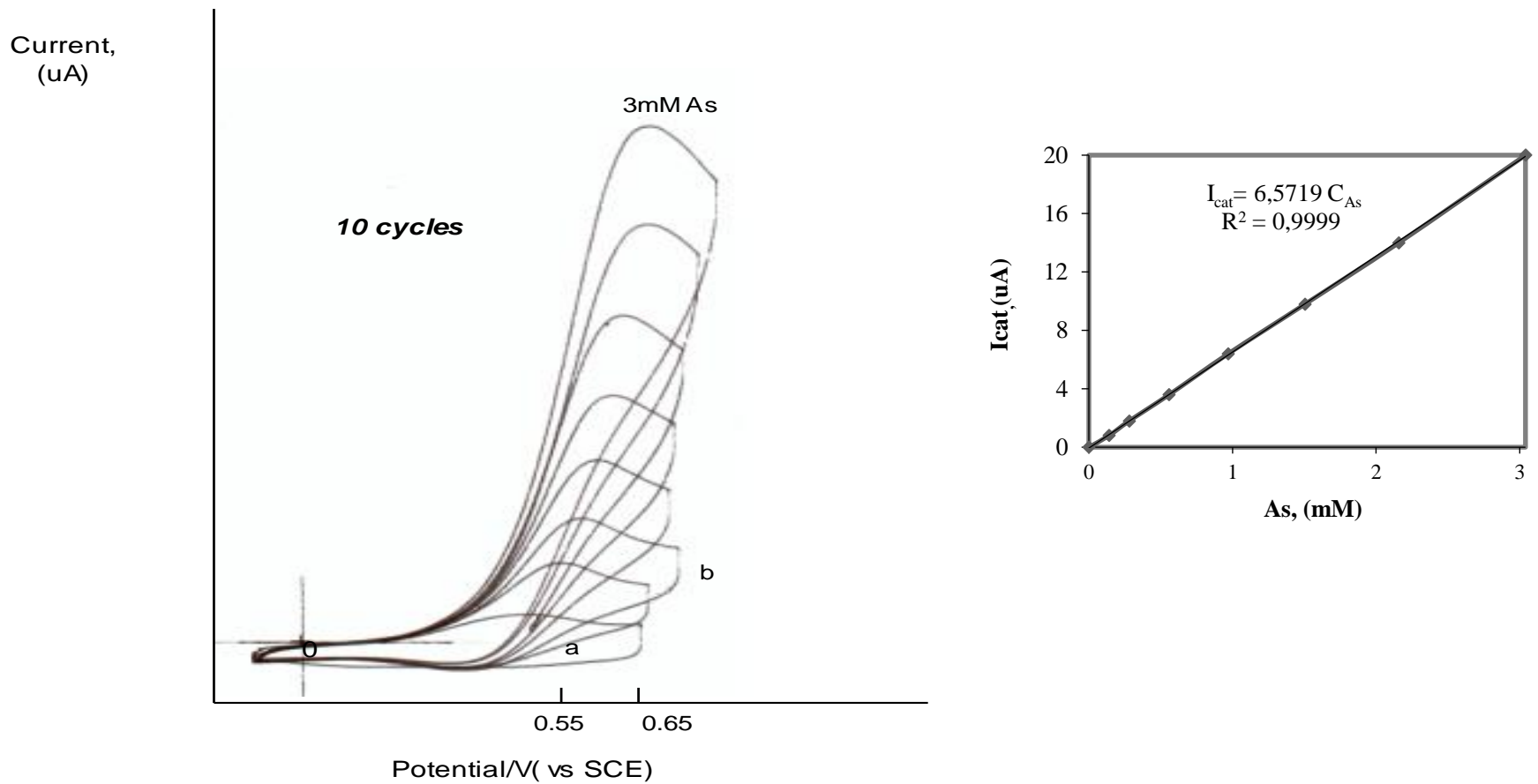

Figure 16. Cyclic voltammograms recorded at a $\left(\mathrm{GC}_{\mathrm{IrO}} \mathrm{I} \mathrm{H}_{2} \mathrm{O}\right), 10$ cycles, in $\mathrm{P}(\mathrm{ClMPTA}) 0.1 \mathrm{M}$ solution, $\mathrm{pH}=9$. Conditions scan rate $10 \mathrm{mV} / \mathrm{s}, 4 \mu \mathrm{A} / \mathrm{cm}, 100$ $\mathrm{mV} / \mathrm{cm}$. (a) in absence of arsenic, (b) $3 \mathrm{mM} \mathrm{As}(\mathrm{III})$. (c) Icat $(\mu \mathrm{A})$ versus As(III) concentration (mM).
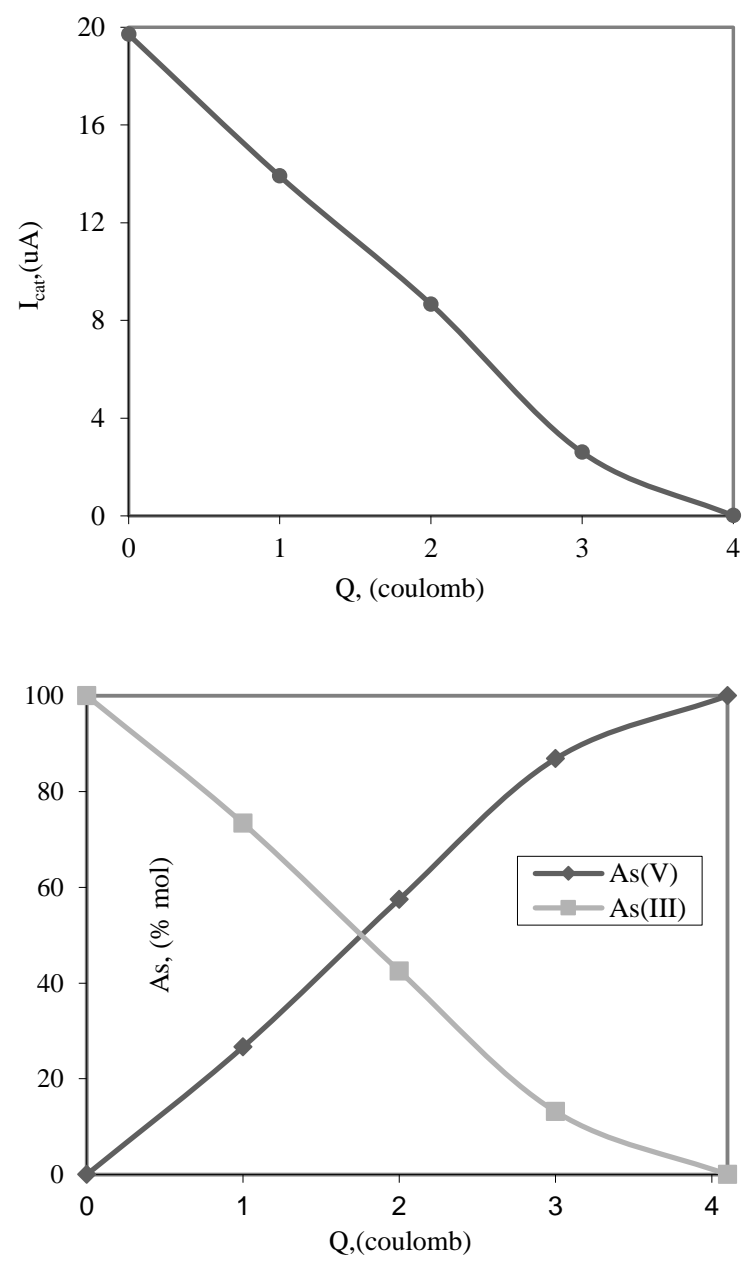

Figure 17. a) Catalytic current, $\mathrm{I}_{\text {cat }}$, changes as a function of applied charge, $\mathrm{Q}$ (coul). b) Conversion of As(III) to As(V), (\%mole), as a function of applied charge, Q (coul).

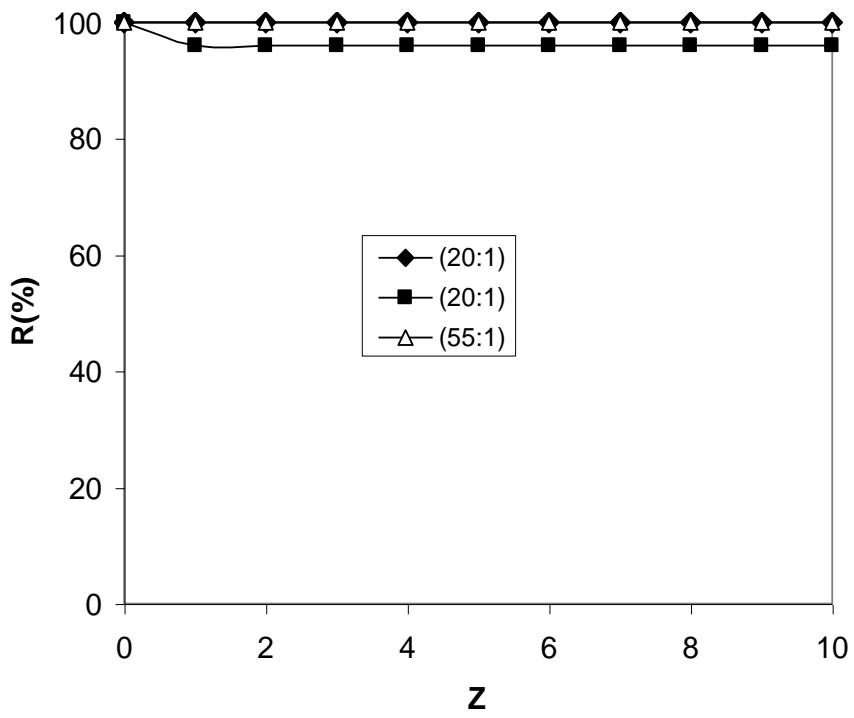

Figure 18. Retention profile of $\mathrm{As}(\mathrm{V})$, produced by electro-oxidation of As(II) on iridium modified carbon electrode. 0.5 MM AS(III) and molar ratio polymer:As(III) of (20:1) and (55:1) at $\mathrm{pH} 8$.

\subsubsection{Ruthenium oxide on polymer film electrodes}

A new film was synthesized with a base of ruthenium oxides, which are able to detect and oxidize As(III) from aqueous solutions. The electrodeposition of metallic oxides in a polymeric film was carried out previous to contact with $\mathrm{K}_{2} \mathrm{RuO}_{4} \cdot \mathrm{H}_{2} \mathrm{O}$ in an aqueous solution and reduction to $\mathrm{RuO}_{2}$ with a constant potential. The catalytic current of the electro-oxidation of As(III) in the presence of $\mathrm{RuO}_{4}=/ \mathrm{RuO}_{2}$ (VI/IV) sites deposited on poly(pyrrol quaternized) film was linear for an $\mathrm{As}(\mathrm{III})$ concentration range of $0.032-3 \mathrm{mM}$. An oxidation potential of $0.52 \mathrm{~V}$ for $\mathrm{As}(\mathrm{III})$ was constant in all concentrations. Quantitative determinations of $\mathrm{As}(\mathrm{V})$ by the electrolysis of $\mathrm{As}(\mathrm{III})$ with felt carbon/poly(PyrrolQ)/ $\mathrm{RuO}_{2}$ and monitoring with a poly $($ PyrrolQ $) / \mathrm{RuO}_{2}$ analytic electrode were realized with $0.1 \mathrm{M} \mathrm{Na}_{2} \mathrm{SO}_{4}$ inorganic polyelectrolytes and a 0.05 M P(ClMPTA) polymer solution. The results show that $99 \%$ of As(III) was converted to $\mathrm{As}(\mathrm{V})[86]$. 


\section{CONCLUSIONS}

The LPR technique demonstrated to be an effective method to remove arsenic from aqueous media. Quaternary ammonium salt polyelectrolytes with different cationic and anionic groups indicated that selectivity on retention depended in positive and negative group nature of polyelectrolyte. Anionic exchanger groups of polyelectrolyte with easier degree hydration are easily exchangeable with arsenate. Therefore, they showed a $100 \%$ retention basic and neutral media. Quaternary ammonium groups with a big alkylated chain size or structures with aromatic rings around increasing the hydrophobicity site reinforcement the site bond. Arsenate anion retention is favored at basic $\mathrm{pH}$, because on chemistry equilibrium divalent species predominate on monovalent, in an electro-selective exchanger as polycationic in study. It is possible to recuperate arsenite ions from aqueous media, by adapting the conditions, on the macro catalytic electroxidation of $\mathrm{As}(\mathrm{III})$ to $\mathrm{As}(\mathrm{V})$ in quaternary ammonium salt polyelectrolyte solution media to recuperation from water in form to $\mathrm{As}(\mathrm{V})$ by $\mathrm{LPR}$ technique.

\section{ACKNOWLEDGEMENTS}

The authors thank to FONDECYT (Grants No 1191336 and No 1150510)

\section{REFERENCES}

1. B. Volesky, Z. Holan. Biotechnol. Prog. 11, 235, (1995).

2. S. Qaiser, A. Saleemi, M. Ahmad. Environ. Biotechnol. 10, 409, (2007).

3. F. Fu, Q. Wang. J. Environ Manage. 92, 407, (2011).

4. D. O’Connell, C. Birkinshaw, T. O’Dwyer. Bioresour. Technol. 99, 6709 , (2008).

5. T. Kurniawan, G. Chan, W. Lo, S. Babel. Chem. Eng. J. 118, 83, (2006)

6. W. Peternele, A. Winkler-Hechenleitner, E. Gomez. Bioresour Technol. 68, 95, (1999)

7. B.L. Rivas, S.A. Pooley, M. Luna. Macromol. Rapid Commun. 21, 905, (2000).

8. B.L. Rivas, H. Maturana, R. Catalan, I. Perich. J. Appl. Polym. Sci. 38, 801, (1989).

9. B.L. Rivas, E. Pereira. Bol. Soc. Chil. Quim. 45, 165, (2000).

10. J. Sanchez, B.L. Rivas, A. Pooley, L. Basaéz, E. Pereira, I. Pignot-Paintrand, C. Bucher, G. Royal, E. Saint-Aman, J. Moutet. Electrochim. Acta 55, 4876, (2010).

11. B.L. Rivas, I. Moreno-Villoslada. Chem. Lett. 2, 66, (2000).

12. B.L. Rivas, H. Maturana, E. Pereira. Angew. Makromol. Chem. 220, 61, (1994).

13. K. Geckeler, R. Zhou, B.L. Rivas. Angew. Makromol. Chem. 197, 107, (1992).

14. S. Tangjuank, N. Insuk, J. Tontrakoon, V. Udeye. World Acad. Sci. Eng. Technol. 28, 110, (2009)

15. S. Cobianco, A. Lezzi, R. Scotti. React. Funct. Polym. 43,7, (2000).

16. M. León-Gonzalez, L. Peréz-Arribas. J. Chromatogr. A. 902, 3, (2000).

17. L. Zhou, Y. Wang, Z. Liu, Q. Huang. J. Hazard Mater. 161, 995, (2009).

18. X. Liu, Q. Hu, Z. Fang, X. Zhang, B. Zhang. Langmuir. 25, 3, (2009).

19. N. Pekel, N. Sahiner, O. Guven. J. Appl. Polym. Sci. 81, 2324, (2001)

20. B.L. Rivas, B. Urbano, J. Sánchez. Front. Chem. 6, 320, (2018).

21. B. Urbano, B.L. Rivas. J, F. Martínez, S.D. Alexandratos. React. Funct. Polym. 72, 642, (2012).

22. B. Urbano, B.L. Rivas. Polym. Bull. 70, 1143, (2013).

23. M. Palencia, B.L. Rivas, E. Pereira, A. Hernández, P. Prádanos, J. Membr. Sci., 336, 128, (2009).

24. A. Atta, H. Al-Lohedan, Z. Alothman, A. Abdel-Khalek, A. Tawfeek. J. Industr. Eng. Chem. 31, 374, (2015).

25. B.L. Rivas, E. Pereira, I. Moreno-Villoslada. Prog. Polym. Sci. 28, 173, (2003).

26. P. Smedley, D. Kinniburgh. Appl. Geochem. 17, 517, (2002).

27. P. Bhattacharya, G. Jacks, K. Ahmed, J. Routh, A. Khan. Bull. Env. Contam. Toxicol. 69, 538, (2002)

28. P. Bhattacharya, D. Chatterjee, G. Jacks. Int. J. Water Resour. D. 13, 79, (1997).

29. P. Bhattacharya, A. H. Welch, K. G. Stollenwerk, M. J. McLaughlin, J. Bundschuh, G. Panaullah. Sci. Total Environ. 379, 109, (2007).

30. J. Bundschuh, M. E. Garcia, P. Birke, L. H. Cumbal, P. Bhattacharya, J. Matschullat, "Occurrence, health effects and remediation of arsenic in groundwaters of Latin America," in Natural Arsenic in Groundwaters of Latin America, J. Bhattacharya, A. B. Matschullat, M. A. Armientan, et al., Eds., pp. 3-15, Taylor \& Francis, London, UK, 2009.
31. P. Bhattacharya, M. Hossain, S. N. Rahman, C. Robinson, B. Nath, M. Rahman, M. Mainul, M. Von, K. Matin, G. Jacks, D. Chowdhury, M. Rahman, M. Jakariya, L. Ake, M. Vahter. J. Environ Sci Health A Tox Hazard Subst Environ Eng, 46, 1177, (2011).

32. P. Ravenscroft, H. Brammer, K. Richards. Arsenic Pollution: A Global Synthesis, John Wiley \& Sons, West Sussex, UK, (2009).

33. U.S. EPA "National primary drinking water regulations: arsenic and clarifications to compliance and new source contaminants monitoring." Federal Register, 2001.

34. WHO, Guidelines for Drinking-Water Quality, vol. 4, World Health Organization, 2011.

35. U.S EPA, "Arsenic in Drinking Water," 2013 http://water.epa.gov/lawsregs/rulesregs/sdwa/arsenic/index.cfm.

36. U.S EPA, "Chemical Contaminant Rules", 2018 https://www.epa.gov/dwreginfo/chemical-contaminant-rules Consultado: 05-07-2019.

37. S. Santra, A. Samal, P. Bhattacharya, S. Banerjee, A. Biswas, J. Majumdar. Procedia Environ. Sci. 18, 2, (2013).

38. A. Rai, P. Tripathi, S. Dwivedi, S. Dubey, M. Shri, S. Kumar, P. Kumar, R. Dave, A. Kumar, R. Singh, B. Adhikari, M. Bag, R. Deo, P. Trivedi, D. Chkrabarty, R. Tuli. Chemosphere. 82, 986, (2011).

39. J. Brinkel, M. Khan, A. Kraemer. Int J. Environ Res Public Health. 6, 1609 (2009).

40. J. Stroud, G. Norton, M. Islam, T. Dasgupta, R. White, A. Price, A. Meharg, S. McGrath, F. Zhao. Environ Pollut. 159, 947, (2011).

41. S. Fendorf, H. Michael, A. van Geen. Science. 328, 1123, (2010).

42. N. Mirlean, P. Baisch, D. Diniz. Sci. Total Environ. 482, 148, (2014).

43. A. Mukherjee, M. Sengupta, M. Hossain, S. Ahamed, B. Das, B. Nayak, D. Lodh, M. Rahman, D. Chakraborti. J Health Popul Nutr. 24, 142, (2006).

44. D. Chakraborti, M. Rahman, B. Das, M. Murrill, S. Dey, S. Mukherjee, R Dhar, B. Biswas, U. Chowdhury, S. Roy, S. Sorif, M. Selim, M. Rahman, Q. Quamruzzaman. Water Res. 44, 5789, (2010).

45. D. Shukla, C. Dubey, N. Singh, M. Tajbakhsh, M. Chaudhry. J. Hydrol. 395 49, (2010).

46. S. Sthiannopkao, K. Kim, S. Sotham, S. Choup. Appl. Geochem. 23, 1086 , (2008).

47. J. Nriagu, P. Bhattacharya, A. Mukherjee, J. Bundschuh, R. Zevenhoven, R Loeppert. Trace Metals and other Contaminants in the Environment. 9, 3 , (2007).

48. M. Khan, Y-S. Ho. Asian J. Chem. 23, 1889, (2011).

49. J. Gómez, J. Lillo, B. Sahún. Environ Geol. 50, 1151, (2006).

50. W. Cutler, R. Brewer, A. El-Kadi, N. Hue, P. Niemeyer, J. Peard, C. Ray. Sci Total Environ. 442, 177, (2013).

51. R. Tuli, D. Chakrabarty, P. Trivedi, R. Tripathi. Mol. Breeding. 26, 307, (2010).

52. Y. Chen, F. Parvez, M. Gamble, T. Islam, A. Ahmed, M. Argos, J. Graziano, H. Ahsan. Toxicol. Appl. Pharmacol. 239, 184, (2009).

53. M. Bissen, F. Frimmel. Acta Hydrochim. Hydrobiol. 31, 9, (2003).

54. J. Pérez, L. Toledo, C. Campos, B.L. Rivas, J. Yañez, B. Urbano. Chem. Eng. J. 287, 744, (2016).

55. J. Perez, L. Toledo, C. Campos, J. Yañez, B.L. Rivas, B. Urbano. RSC Adv. 6, 28379, (2016).

56. M. Hua, B. Yang, C. Shan, W. Zhang, S. He, L. Lv, B. Pan. Chemosphere. 171, 126, (2017)

57. C. Iesan, C. Capat, F. Ruta, I. Udrea. Water Res. 42, 4327, (2008)

58. B. Pan, Z. Li, Y. Zhang, J. Xu, L. Chen, H. Dong, W. Zhang. Chem. Eng. J. 248, 290, (2014).

59. B. Urbano, B.L. Rivas, F. Martinez, S. Alexandratos. Chem. Eng. J. 193, 21 (2012)

60. G. Ungureanu, S. Santos, R. Boaventura, C. Botelho. J. Environ. Manage. 151, 326, (2015)

61. M. Jian, B. Liu, G. Zhang, R. Liu, X. Zhang. Colloids Surf. A Physicochem. Eng. Asp. 465, 67, (2015)

62. T. Vu, G. Le, C. Dao, L. Dang, K. Nguyen, Q. Nguyen, P. Dang, H. Tran, Q. Duong, T. Nguyen, G. Lee. RSD Adv. 5, 5261, (2015)

63. G. Ozkula, B. Urbano, B.L. Rivas, N. Kabay, M. Bryjak. J. Chil. Chem. Soc. 61, 2752, (2016)

64. I. Villenas, B.L. Rivas, C. Campos, B. Urbano. Chem. Eng. J. 268, 362, (2015)

65. N. Pous, B. Casentini, S. Rossetti, S. Fazi, S. Puig, F. Aulenta. J. Hazard Mater. 283, 617, (2015)

66. S. Sorlini, F. Gialdini. Water Res. 44, 5653, (2010).

67. S. Hug, O. Leupin. Environ. Sci. Technol. 37, 2734, (2003)

68. P. Dutta, S. Pehkonen, V. Sharma, A. Ray. Environ. Sci. Technol. 39, 1827, (2005). 
69. M. Emett, G. Khoe. Water Res. 35, 649, (2001).

70. R. Cheng, S. Liang, H. Wang, M. Beuhler. J. Am. Water Work Assoc. 86, 79, (1994).

71. F. Hesami, B. Bina, A. Ebrahimi, M. Amin. Int. J. Environ. Health Eng. 2, 1, (2013).

72. J. Hering, P. Chen, J. Wilkie, M. Elimelech. J. Environ. Eng. 123, 800, (1997).

73. D. Lakshmanan, D. Clifford, G. Samanta. J. Am. Water Work Assoc. 100, 76, (2008)

74. H. Gecol, E. Ergican, A. Fuchs. J. Membr. Sci. 241, 105, (2004).

75. J. Iqbal, H. Kim, J. Yang, K. Baek, J. Yang. Chemosphere. 66, 970, (2007).

76. Y. Sato, M. Kang, T. Kamei, Y. Magara. Water Res. 36, 3371, (2002).

77. M. Uddin, M. Mozumder, A. Figoli, M. Islam, E. Drioli. Indian J. Chem. Technol. 14, 441, (2007).

78. F. Beolchini, F. Pagnanelli, I. De Michelis, F. Veglio. J. Hazard. Mater. 148, 116, (2007).
79. B.L. Rivas, M. Aguirre. J. Appl. Polym. Sci. 106, 1889, (2007).

80. B.L. Rivas, M. Aguirre, E. Pereira. J. Appl. Polym. Sci. 102, 2677, (2006).

81. J. Sánchez, B. Butter, B.L. Rivas, L. Basáez, P. Santander. J. Appl. Electrochem. 45, 151, (2015).

82. J. Sánchez, B.L. Rivas. Desalination 270, 57, (2011).

83. A. Ozgur, N. Kabay, J. Sanchez, B.L. Rivas, M. Bryjak, C. Peña. Environ. Prog. Sustain. 33, 918, (2014).

84. X. Guan, J. Du, X. Meng, Y. Sun, B. Sun, Q. Hu. J. Hazard. Mater. 215, 1, (2012).

85. J. Sánchez, L. Riffo, P. Salazar, B.L Rivas. J. Appl. Polym. Sci. 2019, doi: 10.1002/app.48184.

86. J.F. Rivera, C. Bucher, E. Saint-Aman, B.L. Rivas, M.C. Aguirre, J Sánchez, I. Pignot-Paintrand, J-C. Moutet. Appl. Catal. B-Environ. 129, 130, (2013) 